\title{
Production and characterization of monoclonal antibodies to a Brazilian bovine herpesvirus type 5
}

\section{Oldoni, R. Weiblen, M.A. Inkelmann and E.F. Flores}

Setor de Virologia, Departamento de Medicina Veterinária Preventiva and Departamento de Microbiologia e Parasitologia, Universidade Federal de Santa Maria, Santa Maria, RS, Brasil

\author{
Correspondence \\ E.F. Flores \\ Departamento de Medicina \\ Veterinária Preventiva \\ Universidade Federal de Santa Maria \\ 97105-900 Santa Maria, RS \\ Brasil \\ Fax: +55-55-220-8034 \\ E-mail: flores@ccr.ufsm.br \\ Research supported by MCT, CNPq, \\ CAPES and FINEP (PRONEX in \\ Veterinary Virology, No. 215/96). \\ I. Oldoni is the recipient of a \\ fellowship from CAPES. E.F. Flores \\ and $\mathrm{R}$. Weiblen are recipients of \\ CNPq fellowships (Nos. 520758/96-0 \\ and 520011/95, respectively). \\ M.A. Inkelmann is the recipient of a \\ FAPERGS student fellowship.
}

Received November 22, 2002 Accepted September 30, 2003

\begin{abstract}
Antigens of a bovine herpesvirus type 5 (BHV-5), isolated from a cow with a neurological infection in Rio Grande do Sul State, Brazil, were used to immunize $\mathrm{BALB} / \mathrm{c}$ mice to produce monoclonal antibodies (mAbs). Eleven hybridomas secreting mAbs directed at BHV-5 antigens were obtained after two fusions and screening of 356 hypoxanthine-aminopterin-thymidine-resistant clones. The mAbs reacted at dilutions up to 1:500 (hybridoma culture supernatant) and up to $>1: 10,000$ (ascitic fluid) in an indirect fluorescent antibody assay (IFA) and in immunoperoxidase staining of BHV-5-infected cells. Four mAbs (1D12, 2E2, 2G10 and 4E4) showed virus-neutralizing activity against the parental BHV-5 isolate. Five mAbs (1F3, 2A6, 2F9, 2G10 and HB24L) reacted in Western immunoblotting with a protein of approximately $90 \mathrm{kDa}$. Three other mAbs (2E2, 3D6 and 4E4) reacted in IFA with antigens of a BHV-1 mutant glycoprotein Cnegative strain, demonstrating that they are directed at a viral antigen other than glycoprotein $\mathrm{C}$. The eleven mAbs tested reacted with 20 BHV-5 field isolates and nine mAbs reacted with $10 \mathrm{BHV}-1$ isolates. Two mAbs (1F3 and 2F9) failed to react with BHV-1 field isolates, although they displayed a weak and nonreproducible reaction with the BHV-1 reference strain Los Angeles. These mAbs may be very useful in distinguishing between BHV-1 and BHV-5 infections since most of the traditional reagents and techniques are unable to do so. One $\mathrm{mAb}$ (2F9) was shown to bind to viral antigens by immunohistochemistry of histological sections of the brain of a BHV-5-infected calf. These results demonstrate that the $\mathrm{mAbs}$ produced here are suitable for use in a variety of immunological techniques and therefore may be useful for diagnostic and research purposes.
\end{abstract}

\section{Introduction}

Bovine herpesvirus type 5 (BHV-5) is an $\alpha$-herpesvirus associated with fatal meningoencephalitis in cattle (1). Outbreaks of neurological disease induced by BHV-5 have
Key words

- Bovine herpesvirus type 5 and type 1

- BHV-5

- BHV-1

- Monoclonal antibodies

....................... been frequently described in well-defined geographical regions, mainly Argentina and central/southern Brazil (2-4). Clinical signs of BHV-5-associated neurological disease include tremors, circling, bruxism, incoordination, nystagmus, recumbency followed by 
convulsions, paddling, and inevitably death $(2,4,5)$. Like other $\alpha$-herpesviruses, BHV-5 establishes a lifelong latent infection in sensory nerve ganglia after primary infection $(5,6)$. Viral reactivation and shedding may occur under certain induced or naturally occurring stimuli and provide favorable conditions for viral transmission and spread $(5,7)$.

BHV-5 is genetically and antigenically closely related to the widespread respiratory and genital bovine herpesvirus type 1 (BHV$1)$, so that until recently it was classified as a BHV-1 subtype $(6,8)$. In fact, the recently determined nucleotide sequence of the entire DNA genome of a Brazilian BHV-5 isolate has revealed a nearly identical genome structure and organization and a strikingly high sequence homology with BHV-1 (9). Although some antigenic differences have been detected between the envelope glycoproteins of BHV-1 and BHV-5, the major differences between these viruses are concentrated in the genes encoding the envelope glycoprotein C (9-13). Glycoprotein C is the most abundant envelope glycoprotein, it is involved in the initial interactions of virions with the cell surface, and represents a major target for antibodies with virus-neutralizing activity $(14,15)$. In spite of the differences in the envelope glycoproteins, the traditional serological techniques and the majority of BHV-1 and BHV-5 monoclonal antibodies (mAbs) are unable to distinguish between these two viruses $(16,17)$. Likewise, extensive serological cross-reactivity has been demonstrated between BHV-1 and BHV-5 (17-19). Nevertheless, the occurrence of cross-protection between BHV-1 and BHV5 is still controversial $(8,17,19-22)$. A possible cross-protection between these viruses would be of obvious interest for immunization strategies and vaccine production since only BHV-1 vaccines are available to date (21).

The prevalence and geographical distribution of BHV-5 infection in cattle populations are largely unknown. This is due, in part, to the widespread distribution of BHV-1 infection and vaccination, associated with the inability of traditional techniques to distinguish between BHV-1- and BHV-5-induced antibodies. In this respect, the availability of reagents and techniques to identify and differentiate between BHV-1 and BHV-5 would be of great value for diagnostic and epidemiological purposes. In this article we report the production and characterization of a panel of mAbs against the recently sequenced Brazilian BHV-5 isolate (SV-507) (9). Most of these $\mathrm{mAbs}$ recognized a panel of BHV-1 and BHV5 field isolates and two mAbs were able to differentiate between BHV-1 and BHV-5.

\section{Material and Methods}

\section{Cells and viruses}

Bovine kidney cells (MDBK, ATCC, CCL-22) were propagated in minimal essential medium (MEM) supplemented with $10 \%$ horse serum, 10,000 IU/1 penicillin, $0.2 \mathrm{~g} / 1$ streptomycin, and $2.5 \mathrm{mg} / 1$ fungizone. $\mathrm{Sp} 2$ myeloma cells were propagated in RPMI medium (Sigma, St. Louis, MO, USA) supplemented with $10 \%$ fetal bovine serum (FBS; Gibco-BRL, Rockville, MD, USA), $50 \mu \mathrm{g} / 1$ 8-azaguanine (Sigma), $1 \mathrm{mM}$ sodium pyruvate (Sigma), $2 \mathrm{mM}$ L-glutamine (Sigma), 0.01\% 2-mercaptoethanol (Sigma), and antibiotics as stated above, in a humidified chamber with $5 \% \mathrm{CO}_{2}$. A Brazilian BHV-5 strain (SV-507) isolated from a cow with neurological disease and recently submitted to nucleotide sequencing of the entire DNA genome (9) was used for mouse immunization. The virus was biologically cloned three times prior to production of viral stocks for antigen production. The BHV-1 and BHV-5 isolates used to test the spectrum of reactivity of the mAbs have been previously characterized (20). The double gene-deleted BHV-1 mutant (IBRVdlTKdlgIII) and the parental BHV-1 Los Angeles strain used in the characterization of mAbs have been previously described (23). 
Antigen production and mouse immunization

The cloned BHV-5 isolate SV-507 was used to infect MDBK cells to produce antigen for mouse immunization. Cells were infected at a multiplicity of infection of 1.0 median cell culture infectious dose $\left(\mathrm{CCID}_{50}\right) /$ cell. The culture supernatant was collected approximately $20-24 \mathrm{~h}$ post-infection, when the cytopathic effect reached about $90 \%$ of the monolayer. Following centrifugation at $12,000 \mathrm{~g}$ for $30 \mathrm{~min}$ to remove cell debris, the viral particles from the supernatant were pelleted by centrifugation at $65,000 \mathrm{~g}$ for $2 \mathrm{~h}$ at $4^{\circ} \mathrm{C}$ and resuspended in MEM at 1/100 of the initial volume. The concentrated virus was aliquoted and stored at $-70^{\circ} \mathrm{C}$. For immunization, concentrated virus was mixed with an equivalent volume of adjuvant and injected intraperitoneally (ip) into BALB/c mice (200 $\mu$ in complete Freund's adjuvant (Sigma) at day 0 and $200 \mu 1$ in incomplete Freund's adjuvant (Sigma) at 14, 28 and 42 days after the first inoculation). Concentrated virus $(200 \mu \mathrm{l})$ without adjuvant was injected ip into mice three days prior to removal of the spleen for cell fusion.

\section{Cell fusion, hybridoma selection and screening}

Three days after the last immunization, mice were sacrificed and the spleen was removed and minced and the splenocytes obtained were mixed with $\mathrm{Sp} 2$ cells at a proportion of 10:1 splenocytes per Sp2 cell. Cell fusion was induced with $50 \%$ polyethylene glycol (PEG, MW 1500; Sigma) for 1 min at $37^{\circ} \mathrm{C}$, followed by the slow addition of warm $\left(37^{\circ} \mathrm{C}\right) \mathrm{RPMI}$ medium. The PEGtreated cells were then diluted and plated onto 96-well plates containing hypoxanthineaminopterin-thymidine (HAT) medium (Sigma) supplemented with $15 \%$ FBS. Expanding hybridomas were detected 7 to 10 days after fusion and the supernatant was tested for the presence of BHV-5-specific
$\mathrm{mAbs}$ by indirect fluorescent antibody (IFA) staining. Hybridoma cells secreting BHV-5specific mAbs were then cloned by limiting dilution, propagated and stored in liquid nitrogen.

\section{Indirect fluorescent antibody and immunoperoxidase staining}

The presence of mAbs in the supernatant of each expanding hybridoma culture was tested in MDBK cells infected with the BHV5 isolate SV-507 using IFA and immunoperoxidase (IPX) as previously described (24). Mock-infected MDBK cells were used as controls. The individual mAbs were used as primary antibody and the preparation was incubated with a secondary FITC-conjugated (for IFA; Sigma) or HRPO-conjugated (IPX; Sigma) anti-mouse antibody. The reactivity of each individual $\mathrm{mAb}$ with several $\mathrm{BHV}-1$ and BHV-5 isolates was also determined by IFA as described above.

\section{Production of ascitic fluid}

For each hybridoma clone secreting antiBHV-5 mAbs, two BALB/c mice were primed with Pristane (Sigma) and injected $i p$ with approximately $10^{6}$ hybridoma cells seven days later. Ten days later, the ascitic fluid was collected from the mice, cleared by low speed centrifugation $(3,000 \mathrm{~g}, 10 \mathrm{~min})$, titrated by IFA in BHV-5-infected cells, aliquoted, and stored at $-70^{\circ} \mathrm{C}$. Some hybridoma clones displaying poor growth were not used for production of ascitic fluid.

\section{Monoclonal antibody characterization}

The mAbs produced by HAT-resistant hybridoma clones were characterized in terms of: i) immunoglobulin class and subclass, ii) reaction titer in IFA and IPX, iii) virusneutralizing activity, iv) reactivity with BHV1 and BHV-5 field isolates, v) protein specificity, and vi) binding to BHV-5 antigens in 
deparaffinized histological sections. The immunoglobulin class and subclass were determined using a commercially available kit according to manufacturer instructions (Mouse Type Isotyping kit, BioRad, Hercules, CA, USA). The reaction titer of each $\mathrm{mAb}$ was determined by testing different dilutions of either hybridoma supernatant or ascitic fluid as primary antibody in IFA. The virus-neutralizing activity of the mAbs against the parental SV-507 isolate was investigated by a plaque reduction assay according to protocols previously described (25), using undiluted hybridoma supernatant against approximately $10 \mathrm{CCID}_{50}$ of isolate SV-507. The spectrum of reactivity of each $\mathrm{mAb}$ was assessed by testing cell monolayers infected with different BHV-5 and BHV1 field isolates or reference strains by IFA. Cells infected with isolate SV-507 were used as controls. The protein specificity of the mAbs was investigated by two methods. Initially, the mAbs were tested for their ability to bind to BHV-5 proteins in a standard Western immunoblot assay (26). For mAbs

Table 1. Characterization of monoclonal antibodies (mAbs) produced against antigens of a Brazilian bovine herpesvirus type 5 (BHV-5) isolate.

\begin{tabular}{|c|c|c|c|c|c|c|c|}
\hline \multirow[t]{2}{*}{$\mathrm{mAb}$} & \multirow[t]{2}{*}{ Class } & \multicolumn{2}{|c|}{$\begin{array}{l}\text { Reaction titer } \\
\text { (IFA/IPX) }\end{array}$} & \multicolumn{2}{|l|}{ Reaction in } & \multirow[t]{2}{*}{$\begin{array}{l}\text { Protein } \\
\text { specificity }\end{array}$} & \multirow[t]{2}{*}{$\begin{array}{c}\text { Neutralizing } \\
\text { activity }\end{array}$} \\
\hline & & Ascites & Supernatant & Western blot & $\mathrm{IHC}$ & & \\
\hline HB24L & $\lg \mathrm{G} 1$ & 5,000 & 100 & + & - & $\mathrm{gC}$ & - \\
\hline 1D12 & ND & 100 & 100 & - & ND & $\mathrm{gC}$ & + \\
\hline $1 F 3$ & $\lg M$ & 1,000 & 50 & + & - & $\mathrm{gC}$ & - \\
\hline $2 A 6$ & ND & 500 & 500 & + & - & $\mathrm{gC}$ & - \\
\hline $22 C_{1}$ & ND & NP & 10 & - & - & $\mathrm{gC}$ & - \\
\hline $2 \mathrm{E} 2$ & $\lg G 2 a$ & 10,000 & 50 & - & - & non-gC & + \\
\hline $2 \mathrm{F9}$ & $\operatorname{lgG} 1$ & 10,000 & 500 & + & + & $\mathrm{gC}$ & - \\
\hline $2 \mathrm{G} 10$ & $\lg G 2 b$ & 100 & 10 & + & - & $\mathrm{gC}$ & + \\
\hline $3 \mathrm{D} 6$ & $\operatorname{lgG} 1$ & 500 & 50 & - & - & non-gC & - \\
\hline 4B2 & ND & 100 & 10 & - & ND & $\mathrm{gC}$ & - \\
\hline 4E4 & ND & NP & 100 & - & + & non-gC & - \\
\hline
\end{tabular}

Protein specificity was determined by reaction in Western blot (HB24L, 1F3, 2A6, 2F9, $2 \mathrm{G} 10$ ), or positive reaction with the Los Angeles strain but not with the glycoprotein $C$ (gC) mutant (1D12, 22C1, 4B2) in IFA. + = positive reaction; - = negative reaction; IFA = indirect immunofluorescence; $I \mathrm{HC}=$ immunohistochemistry; IPX = indirect immunoperoxidase staining; $\mathrm{ND}=$ not determined; non-gC $=$ determined by positive reaction with the gC-negative strain $(2 E 2,3 D 6,4 E 4)$ in IFA; NP = not produced. that did not bind to nitrocellulose-immobilized viral proteins, an alternative approach was used to investigate their protein specificity. These mAbs were tested for the ability to bind to viral antigens in MDBK cells infected with a glycoprotein C-deleted BHV1 mutant (IBRVdlTKdlgIII) (23) by IFA. Cells infected with the parental BHV-1 strain (Los Angeles) were used as controls. The ability of individual $\mathrm{mAbs}$ to react with BHV5 antigens in tissues after routine histological processing was investigated by IPX staining of deparaffinized histological sections according to a protocol described previously (24). The IPX was performed on histological sections of the brain of a naturally BHV-5infected calf. Monoclonal antibody MM113, provided by Dr. S. Srikumaran (Department of Veterinary and Biomedical Sciences, University of Nebraska at Lincoln, Lincoln, NE, USA) was used as positive control. Brain sections of a calf who had died of unrelated causes were used as negative control.

\section{Results}

The fusion of splenocytes of BHV-5immunized mice with Sp2 myeloma cells yielded a total of 356 HAT-resistant hybridoma clones. Eleven clones secreted mAbs reacting specifically with $\mathrm{BHV}$-infected cells and several other clones secreted antibodies to cellular components. mAbs secreted by these clones reacted with uninfected MDBK cells. Clones secreting mAbs specifically directed at BHV-5 antigens were then expanded, cloned and stored in liquid nitrogen. Most mAbs were produced both in the supernatant of hybridoma cultures and in mouse ascitic fluid. However, ip inoculation of some hybridoma cell clones into mice did not result in the production of detectable mAbs in the ascitic fluid (Table 1).

The characterization of the mAbs reacting specifically with BHV-5 antigens is summarized in Table 1. The class and subclass of some mAbs could not be determined due to 
a high background and close absorbance for IgG and IgM in the ELISA test used for immunoglobulin typing. All mAbs reacted with BHV-5 antigens both in IFA and IPX at dilutions up to $>10,000$ (ascitic fluid) and up to 500 (hybridoma supernatant). Four mAbs showed neutralizing activity against the parental BHV-5 isolate in a plaque reduction assay. The undiluted supernatant of these hybridoma cultures was able to completely inhibit SV-507 plaque formation by approximately $100 \mathrm{CCID}_{50}$.
All mAbs reacted with antigens of all 20 BHV-5 field isolates tested and nine mAbs reacted with ten BHV-1 field isolates and reference strains (Table 2). Two mAbs (1F3 and 2F9) failed to react with antigens of BHV-1 field isolates. These mAbs reacted only with the standard strain Los Angeles. However, the fluorescence pattern produced by binding to antigens of this strain was very weak and not reproducible compared to binding to BHV-5 isolates (data not shown). Therefore, these mAbs may be used to dif-

Table 2. Reactivity of monoclonal antibodies produced against antigens of a Brazilian bovine herpesvirus type 5 (BHV-5) isolate, with BHV-5 and BHV-1 field isolates and laboratory reference strains ${ }^{\mathrm{a}}$.

\begin{tabular}{|c|c|c|c|c|c|c|c|c|c|c|c|c|}
\hline \multirow[t]{2}{*}{ Isolate/origin } & \multirow[t]{2}{*}{ Type } & \multicolumn{11}{|c|}{ Monoclonal antibody } \\
\hline & & 3D6 & $1 \mathrm{F3}$ & HB24L & 4B2 & $2 \mathrm{Fg}$ & 2E2 & $2 A 6$ & 1D12 & $2 \mathrm{G} 10$ & $22 \mathrm{C} 1$ & 4E4 \\
\hline Los Angeles ${ }^{b}$ & BHV-1 & + & $(+)$ & + & + & $(+)$ & + & + & + & + & + & + \\
\hline IBRVdITKdlg||lb & BHV-1 & + & - & - & - & - & + & - & - & - & - & + \\
\hline Cooperb & BHV-1 & + & - & + & + & - & + & + & + & + & + & + \\
\hline SV-265/96C & BHV-1 & + & - & + & + & - & + & + & + & + & + & + \\
\hline Retirod & BHV-1 & + & - & + & + & - & + & + & + & + & + & + \\
\hline EVI-123/98d & $\mathrm{BHV}-1$ & + & - & + & + & - & + & + & + & + & + & + \\
\hline SV-56/90c & BHV-1 & + & - & + & + & - & + & + & + & + & + & + \\
\hline SV-453/93C & BHV-1 & + & - & + & + & - & + & + & + & + & + & + \\
\hline 009d & BHV-1 & + & - & + & + & - & + & + & + & + & + & + \\
\hline $\mathrm{RP}^{\mathrm{d}}$ & BHV-5 & + & + & + & + & + & + & + & + & + & + & + \\
\hline ISO-97/45e & BHV-5 & + & + & + & + & + & + & + & + & + & + & + \\
\hline EVI-345/96 d & BHV-5 & + & + & + & + & + & + & + & + & + & + & + \\
\hline EVI-88/95d & BHV-5 & + & + & + & + & + & + & + & + & + & + & + \\
\hline P-169/97e & BHV-5 & + & + & + & + & + & + & + & + & + & + & + \\
\hline EVI-340/96 ${ }^{d}$ & BHV-5 & + & + & + & + & + & + & + & + & + & + & + \\
\hline $613^{f}$ & BHV-5 & + & + & + & + & + & + & + & + & + & + & + \\
\hline SV-160/96C & BHV-5 & + & + & + & + & + & + & + & + & + & + & + \\
\hline ISO-97/27e & BHV-5 & + & + & + & + & + & + & + & + & + & + & + \\
\hline ISO-169/96e & BHV-5 & + & + & + & + & + & + & + & + & + & + & + \\
\hline SV-136/98c & BHV-5 & + & + & + & + & + & + & + & + & + & + & + \\
\hline SV-109c & BHV-5 & + & + & + & + & + & + & + & + & + & + & + \\
\hline SV-153/90C & BHV-5 & + & + & + & + & + & + & + & + & + & + & + \\
\hline SV-136/90C & BHV-5 & + & + & + & + & + & + & + & + & + & + & + \\
\hline ISO-97/98e & BHV-5 & + & + & + & + & + & + & + & + & + & + & + \\
\hline SV-642/99c & BHV-5 & + & + & + & + & + & + & + & + & + & + & + \\
\hline SV-190/00C & BHV-5 & + & + & + & + & + & + & + & + & + & + & + \\
\hline SV-1613/93C & BHV-5 & + & + & + & + & + & + & + & + & + & + & + \\
\hline$P-160 / 87^{d}$ & BHV-5 & + & + & + & + & + & + & + & + & + & + & + \\
\hline SV-55/02C & BHV-5 & + & + & + & + & + & + & + & + & + & + & + \\
\hline
\end{tabular}

$+=$ positive reaction; $(+)=$ weak and nonreproducible reaction; $-=$ negative reaction. a Assayed by indirect immunofluorescence; monoclonal antibodies 24F1 and 2D8 were not characterized. bDepartment of Veterinary and Biomedical Sciences, UNL, Lincoln, Nebraska. 'Virology Section, Universidade Federal de Santa Maria (SV/UFSM); dVirology team, Centro de Pesquisas Veterinárias Desidério Finamor (CPVDF); elnstituto Biológico de São Paulo (IBSP-SP); fFaculdade de Medicina Veterinária, Universidade Federal de Pelotas (UFPel); 9 Instituto Nacional de Tecnologia Agropecuária, Balcarce, Argentina (INTA). 
ferentiate BHV-1 from BHV-5 isolates.

Western blot analysis of BHV-5-infected cell lysates, using individual $\mathrm{mAbs}$ as primary antibody revealed that $\mathrm{mAbs} 1 \mathrm{~F} 3,2 \mathrm{~A} 6$, $2 \mathrm{~F} 9,2 \mathrm{G} 10$ and $\mathrm{HB} 24 \mathrm{~L}$ reacted with a protein of approximately $90 \mathrm{kDa}$ in BHV-5-

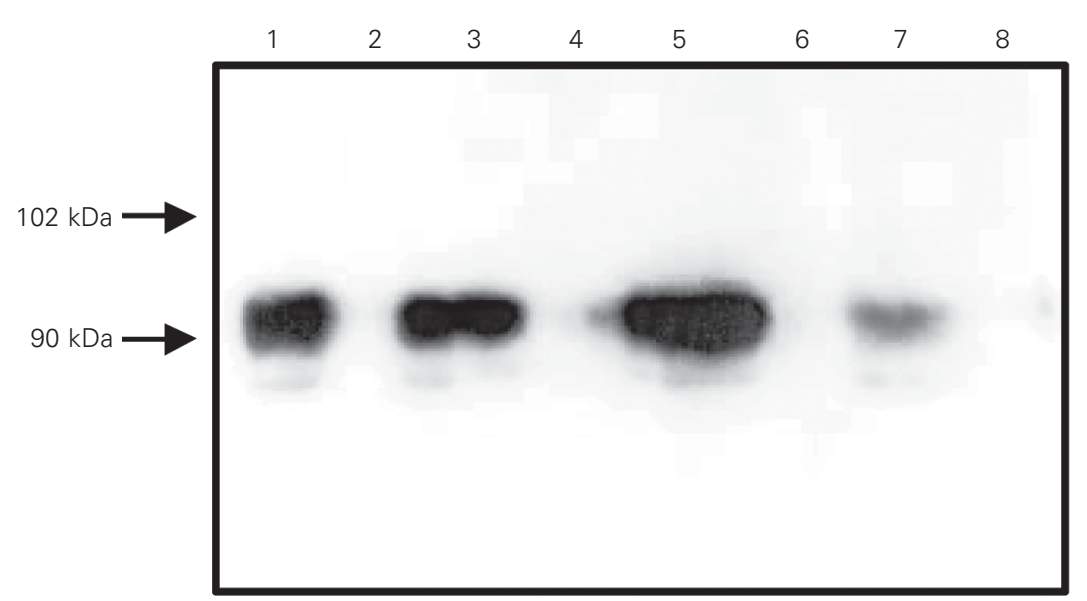

Figure 1. Western blot analysis of bovine herpesvirus type 5- (BHV-5) infected cells. Lysates of BHV-5-infected (lanes 1, 3, 5 and 7) or mock-infected (lanes 2, 4, 6 and 8) MDBK cells were resolved by SDS-PAGE and transferred to a nitrocellulose membrane. Viral proteins were detected using mAb 2F9 (1:1000 dilution, lanes 1 and 2), 1F3 (1:1000 dilution, lanes 3 and 4), HB24L (1:500 dilution, lanes 5 and 6) or 2G10 (1:200 dilution, lanes 7 and 8) followed by an anti-mouse IgG HRPO-conjugated antibody. The signal was detected by enhanced chemiluminescence using the Amersham detection kit. Arrows indicate the positions of the molecular weight markers.

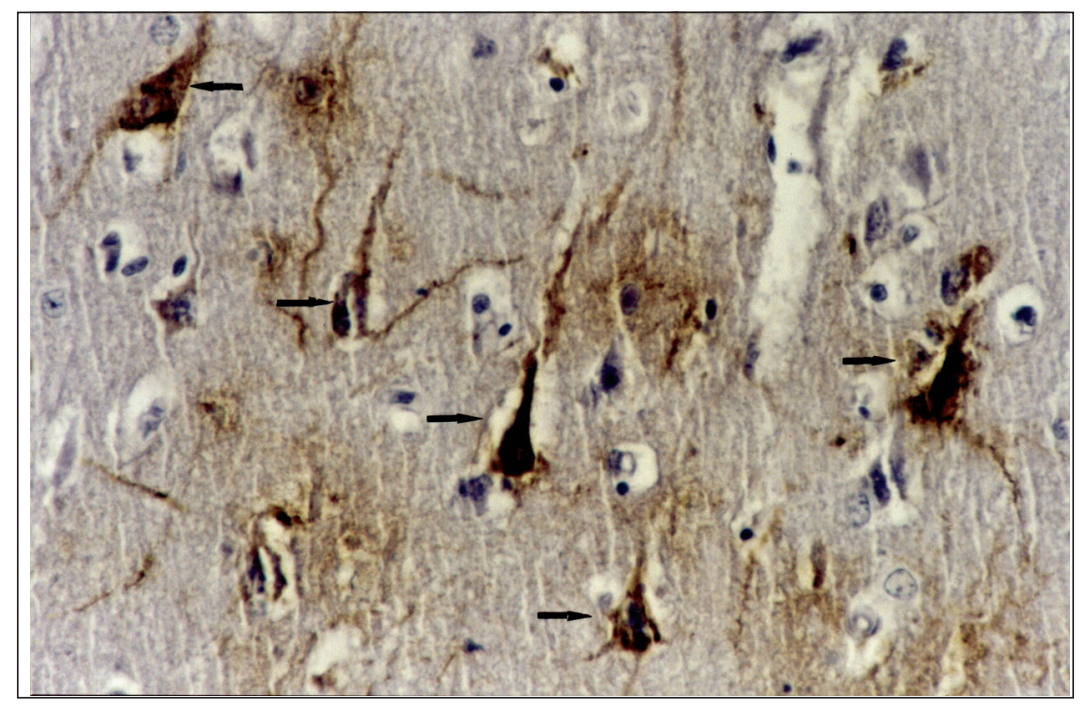

Figure 2. Immunoperoxidase staining of a brain section of a bovine herpesvirus type 5 (BHV-5)-infected calf. BHV-5 antigen in neurons of the cerebral cortex (arrows). Avidinbiotin peroxidase detection system using mAb 2F9. Substrate: diaminobenzidine. Hematoxylin counterstaining. Magnification 320X. infected cells (Figure 1, lanes 1, 3, 5 and 7) but not in mock-infected cells (Figure 1, lanes 2, 4, 6 and 8). The other mAbs failed to react with nitrocellulose-bound viral proteins (data not shown). Thus, to investigate the protein specificity of these mAbs, MDBK cell monolayers infected with either a glycoprotein C-deleted BHV-1 mutant (IBRVdl TKdlgIII) or its parental strain (Los Angeles) were submitted to IFA using each of these $\mathrm{mAbs}$ as primary antibody. Three mAbs (2E2, 3D6 and 4E4) reacted with antigens of the glycoprotein C-negative strain and with antigens of the parental Los Angeles strain as well (data not shown). Therefore, these mAbs are probably directed at a viral antigen other than glycoprotein $\mathrm{C}$. The other $\mathrm{mAbs}$ that failed to react in Western blot (1D12, 22C1, 4B2) reacted with antigens of the parental virus (Los Angeles) but failed to react with cells infected with the glycoprotein $\mathrm{C}$ mutant, indicating that they are directed at glycoprotein $\mathrm{C}$ (data not shown).

The ability of the mAbs to bind to viral proteins in tissues submitted to routine histological processing (i.e., formalin fixation and paraffin embedding) was assayed by immunohistochemistry. Among all mAbs tested, only $\mathrm{mAb} 2 \mathrm{~F} 9$ reacted with viral antigens in neurons of brain sections of a BHV-5-infected calf(Figure 2). The binding was specific since no staining was observed in brain sections of a calf which died of unrelated causes used as negative control (data not shown).

\section{Discussion}

We report the production of $11 \mathrm{mAbs}$ against antigens of a Brazilian BHV-5 isolate. The characterization of these mAbs indicates that they may have potential application for diagnostic and research purposes.

Five of the $11 \mathrm{mAbs}$ recognized a protein of approximately $90 \mathrm{kDa}$, likely glycoprotein $\mathrm{C}$, in Western blot (Figure 1). Previous studies reported that BHV-1 glycoprotein $\mathrm{C}$ has a molecular mass of approxi- 
mately $97 \mathrm{kDa}$ and is slightly larger than its BHV-5 counterpart $(11,12)$. Consistent with these findings, nucleotide sequencing revealed that the BHV-5 glycoprotein $\mathrm{C}$ open reading frame is 50 amino acid shorter than the BHV-1 glycoprotein $\mathrm{C}$ open reading frame (10), explaining the differences in protein sizes observed. The predominance of glycoprotein C-specific mAbs over other protein specificities was not a surprising finding since glycoprotein $\mathrm{C}$ is the most abundant BHV- $1 / 5$ envelope glycoprotein and is highly immunogenic $(14,15)$. Other articles describing the production or the use of BHV1 and BHV-5 mAbs also reported the predominance of $\mathrm{mAbs}$ specific to glycoprotein C over other proteins $(11,12,25)$. Glycoprotein D and glycoprotein B are the other immunodominant viral proteins reported in some of these articles $(11,12,25)$.

Three of the glycoprotein C-specific $\mathrm{mAbs}$ and another $\mathrm{mAb}$ of undetermined protein specificity showed neutralizing activity against isolate $\mathrm{SV}-507$ in a plaque reduction assay. Previous studies have demonstrated that most BHV-1- and BHV-5neutralizing $\mathrm{mAbs}$ are directed against glycoprotein C, although anti-glycoprotein Band anti-glycoprotein D-neutralizing $\mathrm{mAbs}$ have also been reported (11-13,25,27). These neutralizing $\mathrm{mAbs}$ may be useful in mapping neutralizing epitopes in the respective envelope glycoproteins.

Although glycoprotein $\mathrm{C}$ is among the most variable $\mathrm{BHV}-1 / 5$ proteins (9-11), the profile of reactivity of our glycoprotein $\mathrm{C}$ specific $\mathrm{mAbs}$ demonstrated that this glycoprotein appears to harbor a number of immunodominant conserved epitopes. In fact, alignment of the predicted amino acid sequences showed that most differences between BHV-1 and BHV-5 glycoprotein C are concentrated in the amino-terminal third of the protein (only $23.5 \%$ amino acid homology in this region) (10). In contrast, the carboxy-terminal two thirds of these glycoproteins showed a high $(90.0 \%)$ homology
(10). The high degree of homology in this region explains the cross-reactivity of a number of BHV-1 and BHV-5 glycoprotein C $\mathrm{mAbs}$ and may contribute to the extensive cross-neutralization observed between these viruses $(10-12,16,20,27)$. The moderate to low antigenic diversity of other envelope glycoproteins involved in virus neutralization by antibodies (namely glycoprotein B and glycoprotein D) may also contribute to the high cross-neutralization between BHV1 and BHV-5 $(11,13,25)$.

Although a number of BHV-1 and BHV5 glycoprotein $\mathrm{C}$ mAbs have been shown to cross-react, some mAbs with the ability to distinguish between BHV-1 and BHV-5 (as shown for mAbs $1 \mathrm{~F} 3$ and $2 \mathrm{~F} 9$ ) have also been reported $(11,12,20)$. Nucleotide sequencing and epitope mapping have shown that most of BHV-1 and BHV-5 glycoprotein $\mathrm{C}$-specific epitopes are located within the amino-terminal region of the protein (10). The availability of such mAbs may be relevant for diagnostic purposes since they would allow distinction between respiratory/ genital and neurotropic infections by BHV. However, it would be necessary to test a higher number of field isolates to ascertain whether mAbs $1 \mathrm{~F} 3$ and $2 \mathrm{~F} 9$ can conclusively differentiate between these viruses.

mAbs against viral proteins have been widely used for diagnostic and research purposes. The detection of viral proteins in histological sections by immunohistochemistry has been particularly useful in retrospective investigations and pathogenesis studies $(24,28,29)$. Unfortunately, only a small percentage of virus-specific mAbs has been shown to bind to viral proteins after routine histological processing, even after diverse and tiresome antigen retrieval protocols. In this respect, $\mathrm{mAb} 2 \mathrm{~F}$, which reacted specifically with BHV-5 antigens in deparaffinized brain sections of a BHV-5-infected calf, may be particularly useful for diagnostic and pathogenesis studies of histological sections. Moreover, this $\mathrm{mAb}$ can distinguish between 
BHV-1 and BHV-5 antigens.

In summary, the immunization of mice with antigens of a Brazilian BHV-5 isolate followed by fusion with $\mathrm{Sp} 2$ myeloma cells yielded 11 hybridomas secreting virus-specific mAbs with potential applications in diagnosis and research. Most mAbs showed a broad spectrum of reactivity with BHV-1 and BHV-5 isolates, two mAbs were capable to discriminate between BHV-1 and $\mathrm{BHV}-5$, and at least one $\mathrm{mAb}$ was shown to bind to viral antigens in histological sections and may be very useful for diagnostic and pathogenesis studies and for retrospective epidemiological investigations as well.

\section{Acknowledgments}

We thank Dr. Cláudio W. Canal and Dr. Alexandre Leal, Faculdade de Veterinária,
Universidade Federal do Rio Grande do Sul, Porto Alegre, RS, Brazil, for determining the immunoglobulin class and subclass; Dr. S. Srikumaran, Department of Veterinary and Biomedical Sciences, University of Nebraska at Lincoln (UNL), Lincoln, NE, USA, for providing the mAb MM113; Dr. Paulo M. Roehe, Centro de Pesquisas Veterinárias Desidério Finamor, Eldorado do Sul, RS, Brazil, and Dr. Fernando A. Osorio, Department of Veterinary and Biomedical Sciences, $\mathrm{UNL}$, for providing some of the BHV-1 and BHV-5 isolates, and Dr. J. Aleixo, Centro de Biotecnologia, Universidade Federal de Pelotas, Pelotas, RS, Brazil, for providing the Sp2 myeloma cells and BALB/c mice. The help with animal care and handling by the students in our laboratory is greatly appreciated.

\section{References}

1. Roizmann B, Desrosiers RC, Fleckenstein B, Lopez C, Minson AC \& Studdert MJ (1992). The family Herpesviridae: an update. The Herpesvirus Study Group of the International Committee on Taxonomy of Viruses. Archives of Virology, 123: 425-488.

2. Carrillo BJ, Ambrogi A, Schudel AA, Vazquez M, Dahme E \& Pospischil A (1983). Meningoencephalitis caused by IBR virus in calves in Argentina. Zentralblatt für Veterinaermedizin Reihe B, 30: 327-332.

3. Weiblen R, Barros CS, Canabarro TF \& Flores IE (1989). Bovine meningoencephalitis from IBR virus. Veterinary Record, 124: 666667.

4. Salvador SC, Lemos RAA, Riet-Correa F, Roehe PM \& Osório ALAR (1998). Meningoencefalite em bovinos causada por herpesvírus bovino-5 no Mato Grosso do Sul e São Paulo. Pesquisa Veterinária Brasileira, 18: 76-83.

5. Perez SE, Bretschneider G, Leunda MR, Osorio EA, Flores EF \& Odeon AC (2002). Primary infection, latency, and reactivation of bovine herpesvirus type 5 in the bovine nervous system. Veterinary Pathology, 39: 437-444.

6. Belknap EB, Collins JK, Ayers VK \& Schultheiss PC (1994). Experimental infection of neonatal calves with neurovirulent bovine herpesvirus type 1.3. Veterinary Pathology, 31: 358-365.

7. Rock DL (1993). The molecular basis of latent infections by alphaherpesviruses. Seminars in Virology, 4: 157-165.

8. Bulach DM \& Studdert MJ (1990). Comparative genome mapping of bovine encephalitis herpesvirus, bovine herpesvirus 1, and buffalo herpesvirus. Archives of Virology, 113: 17-34.

9. Delhon G, Moraes MP, Lu Z, Afonso CL, Flores EF, Weiblen R, Kutish GF \& Rock DL (2003). Genome of bovine herpesvirus 5.
Journal of Virology, 77: 10339-10347.

10. Chowdhury SI (1995). Molecular basis of antigenic variation between the glycoproteins $\mathrm{C}$ of respiratory bovine herpesvirus 1 (BHV1) and neurovirulent BHV-5. Virology, 213: 558-568.

11. Collins JK, Ayers VK, Whetstone CA \& van Drunen Littel-van den Hurk S (1993). Antigenic differences between the major glycoproteins of bovine herpesvirus type 1.1 and bovine encephalitis herpesvirus type 1.3. Journal of General Virology, 74: 1509-1517.

12. Friedli $K$ \& Metzler AE (1987). Reactivity of monoclonal antibodies to proteins of a neurotropic bovine herpesvirus $1(\mathrm{BHV}-1)$ strain and to proteins of representative BHV-1 strains. Archives of Virology, 94: 109-122.

13. Abdelmagid OY, Minocha HC, Collins JK \& Chowdhury SI (1995). Fine mapping of bovine herpesvirus-1 (BHV-1) glycoprotein D (gD) neutralizing epitopes by type-specific monoclonal antibodies and sequence comparison with BHV-5 gD. Virology, 206: 242-253.

14. Liang $X$, Babiuk LA \& Zamb TJ (1992). An in vivo study of a glycoprotein glll-negative bovine herpesvirus 1 (BHV-1) mutant expressing beta-galactosidase: evaluation of the role of glll in virus infectivity and its use as a vector for mucosal immunization. Virology, 189: 629-639.

15. Okazaki K, Matsuzaki T, Sugahara Y, Okada J, Hasebe M, Iwamura Y, Ohnishi M, Kanno T, Shimizu M \& Honda E (1991). BHV-1 adsorption is mediated by the interaction of glycoprotein glll with heparinlike moiety on the cell surface. Virology, 181: 666-670.

16. Almeida RS (1997). Produção e caracterização de anticorpos monoclonais contra antígenos do herpesvírus da encefalite bovina (BHV-5). Master's thesis, Faculdade de Veterinária, Universidade Federal do Rio Grande do Sul, Porto Alegre, RS, Brazil. 
17. Bratanich AC, Sardi SI, Smitsaart EN \& Schudel AA (1991). Comparative studies of BHV-1 variants by in vivo-in vitro tests. Zentralblatt für Veterinaermedizin Reihe B, 38: 41-48.

18. Vogel FSF, Flores EF, Weiblen R \& Kunrath CF (2002). Atividade neutralizante anti-herpesvírus bovino tipo 1 (BHV-1) e 5 (BHV-5) no soro de bovinos imunizados com vacinas comerciais contra o $\mathrm{BHV}$ 1. Ciência Rural, 32: 881-883.

19. Teixeira MB, Esteves PA, Coelho CSS, Silva TCS, Oliveira IG \& Roehe PM (1998). Diferenças em níveis de anticorpos neutralizantes contra herpesvírus bovino tipo 1 (BVH-1) e 5 (BHV-5). Pesquisa Agropecuária Gaúcha, 4: 61-65.

20. Souza VF, Melo SV, Esteves PA et al. (2002). Caracterização de amostras de herpesvírus tipo 1 (BHV-1) e 5 (BHV-5) com anticorpos monoclonais. Pesquisa Veterinária Brasileira, 22: 13-18.

21. Beltrão N, Flores EF, Weiblen R, Silva AM, Roehe PM \& Irigoyen LF (2000). Infecção e enfermidade neurológica pelo herpesvírus bovino tipo 5 (BHV-5): coelhos como modelo experimental. Pesquisa Veterinária Brasileira, 20: 144-150.

22. Cascio KE, Belknap EB, Schultheiss PC, Ames AD \& Collins JK (1999). Encephalitis induced by bovine herpesvirus 5 and protection by prior vaccination or infection with bovine herpesvirus 1. Journal of Veterinary Diagnostic Investigation, 11: 134-139.

23. Kit S, Kit M \& Otsuka H (1990). US patent number 4992051 and
5128129. US Patent Office, Washington, DC

24. Scherer CF, Flores EF, Weiblen R, Caron L, Irigoyen LF, Neves JP \& Maciel MN (2001). Experimental infection of pregnant ewes with bovine viral diarrhea virus type-2 (BVDV-2): effects on the pregnancy and fetus. Veterinary Microbiology, 79: 285-299.

25. Shen DT, Burger D, Li Z \& Gorham JR (1991). Characterization of monoclonal antibodies to bovine herpesvirus type I, Los Angeles strain. Veterinary Microbiology, 28: 25-37.

26. Tobias FL, Odeon A, Pituco EM, Weiblen R, Garcez DCP \& Flores EF (2000). Análise antigênica e molecular de amostras citopáticas do vírus da diarréia viral bovina. Ciência Rural, 30: 129-135.

27. Egyed L, Brocchi E, Rusvai M \& Bartha A (1992). Study of bovine herpesvirus type 1 strains with monoclonal antibodies. Acta Veterinaria Hungarica, 40: 225-230.

28. d'Offay JM, Ely RW, Baldwin CA, Whitenack DL, Stair EL \& Collins JK (1995). Diagnosis of encephalitic bovine herpesvirus type 5 (BHV-5) infection in cattle: virus isolation and immunohistochemical detection of antigen in formalin-fixed bovine brain tissues. Journal of Veterinary Diagnostic Investigation, 7: 247-251.

29. Ely RW, d'Offay JM, Ruefer AH \& Cash CY (1996). Bovine herpesviral encephalitis: a retrospective study on archived formalin-fixed, paraffin-embedded brain tissue. Journal of Veterinary Diagnostic Investigation, 8: 487-492. 